\title{
1 Acidification diminishes diatom silica production in the Southern Ocean
}

2

3 Katherina Petrou $^{1 *}$, Kirralee G. Baker ${ }^{1,2}$, Daniel A. Nielsen ${ }^{1}$, Alyce M. Hancock ${ }^{3,4,5}$, Kai G. Schulz ${ }^{6}$, 4 Andrew T. Davidson ${ }^{5,7}$

5

6 1. School of Life Science, University of Technology Sydney, 15 Broadway, Ultimo, NSW, 2007

7 Australia

8 2. School of Biological Sciences, University of Essex, Colchester, CO4 3SQ, United Kingdom

9 3. Institute for Marine and Antarctic Studies, University of Tasmania, 20 Castray Esplanade, Battery Point TAS 7004, Australia

4. Antarctic Gateway Partnership, 20 Castray Esplanade, Battery Point TAS 7004, Australia

5. Antarctic Climate \& Ecosystems Cooperative Research Centre, 20 Castray Esplanade, Battery Point TAS 7004, Australia

6. Centre for Coastal Biogeochemistry, Southern Cross University, Military Rd, East Lismore, NSW, 2480, Australia

7. Australian Antarctic Division, Department of Environment and Energy, 203 Channel Hwy, Kingston TAS 7050, Australia

*Author for correspondence: Katherina Petrou

Phone: +61 295144159

Email: Katherina.Petrou@uts.edu.au

Keywords: Ocean acidification, diatoms, silicification, Antarctica, phytoplankton, carbon and silica export, biogeochemistry 


\section{Abstract}

26 Diatoms, large bloom-forming marine microorganisms, build frustules out of silicate, which ballasts

27 the cells and aids their export to the deep ocean. This unique physiology forges an important link 28 between the marine silicon and carbon cycles. However, the effect of ocean acidification on their 29 silicification is unclear. Here we show that diatom silicification strongly diminishes with increased 30 acidity in a natural Antarctic community. Analyses of single cells from within the community, reveal 31 that the effect of reduced $\mathrm{pH}$ on silicification differs among taxa, with several species having 32 significantly reduced silica incorporation at $\mathrm{CO}_{2}$ levels equivalent to those projected for 2100 . These

33 findings suggest that before the end of this century ocean acidification may influence the carbon and 34 silicon cycle by both altering the composition of the diatom assemblages and reducing cell ballasting, which will likely alter vertical flux of these elements to the deep ocean. 
The oceans have absorbed more than $40 \%$ of anthropogenic carbon emissions ${ }^{1,2}$ causing measurable acidification (-0.1 $\mathrm{pH}$ units). End of the century scenarios project a further decrease in ocean $\mathrm{pH}$ of up to 0.4 units $^{3}$. The majority of this $\mathrm{CO}_{2}$ is taken up by the Southern Ocean ${ }^{1}$, causing the buffering capacity and calcium carbonate saturation states of these waters to decline at a faster rate than the global average ${ }^{2}$. Consequently, Antarctic marine ecosystems are amongst the most immediately vulnerable to ocean acidification (OA). Changes in ocean $\mathrm{pH}$ have been shown to have consequences on marine calcifying organisms $^{3-6}$, but less is known about non-calcifying marine phytoplankton. To date, studies on the effect of OA on non-calcifying phytoplankton have reported positive $e^{7-13}$, negative ${ }^{14,15}$ and neutral ${ }^{16,17}$ responses, highlighting the intrinsic variability amongst phytoplankton and underscoring the need for further investigation.

Diatoms are a key group of non-calcifying marine phytoplankton, responsible for $\sim 40 \%$ of ocean productivity ${ }^{18}$. They are unique amongst the phytoplankton in their requirement for silicic acid to produce their silica cell walls (frustules) ${ }^{19}$. This dense, glass-like armour, which is believed to have evolved as a defence against grazers ${ }^{20,21}$, aids sinking, making them important vectors for exporting carbon to ocean depths ${ }^{22-25}$. However, not all diatoms are equal. The specific combination of growth, productivity and silica content determines a species' influence on biogeochemistry and carbon export capacity $^{20,25,26}$. Changes to any of these traits can therefore have consequences for the efficiency of the biological carbon pump, the process by which $\mathrm{CO}_{2}$ is converted to organic carbon via photosynthesis and sequestered to ocean depth through sinking particles. Current understanding of the impacts of OA on diatoms is limited to its effect on growth ${ }^{8,11,12,27}$, community composition ${ }^{8,12,28-32}$ and productivity ${ }^{8,}$ ${ }^{13,32-34}$, in many cases showing positive responses with increased $p \mathrm{CO}_{2}{ }^{11,32}$. While some studies have looked at the mechanistic relationship between $\mathrm{pH}$ and silica biomineralisation ${ }^{35}$, 36, few have investigated environmental $\mathrm{pH}$ shifts on silicification rates in diatoms ${ }^{37,38}$, the unique process that underpins their sinking capacity. Consequently, there is insufficient information to estimate the effect of OA on silica incorporation by diatoms. 
Accurate predictions of how climate change will influence ocean biogeochemistry are constrained by our limited knowledge of the complex biological interactions and individual physiologies that regulate the biological carbon pump. Many key community responses to OA have been identified through mesocosm studies, which can provide certain advantages over smaller, monospecific studies ${ }^{39}$. For instance, the inclusion of mixed assemblages in large volumes, means that natural variability and ecological interactions within and among trophic levels are incorporated, resulting in better representation of treatment responses, scalability, and therefore greater predictive value $\mathrm{e}^{40}$. Here, we use mesocosms to investigate the effect of ocean acidity on Antarctic diatom silicification. We combined community-level response measurements with single cell analyses, to determine the overall effect of OA on diatom silicification and the contribution of individual taxa to the community response.

\section{High $\mathrm{CO}_{2}$ reduces community silicate}

A six-level $\mathrm{CO}_{2}$ dose-response experiment was conducted on a natural Antarctic microbial community using seawater (200 $\mu \mathrm{m}$ filtered) collected approximately $1 \mathrm{~km}$ offshore of Davis Station, Antarctica $\left(68^{\circ} 35^{\prime} \mathrm{S}, 77^{\circ} 58^{\prime} \mathrm{E}\right)$ on the $19^{\text {th }}$ of November 2014 (see Methods). To generate a $\mathrm{CO}_{2}$ gradient, mesocosms $(650 \mathrm{~L})$ were amended with $\mathrm{CO}_{2}$ saturated seawater (see Methods), with the average fugacity of $\mathrm{CO}_{2}\left(f \mathrm{CO}_{2}\right)$ ranging from $343-1641 \mu$ atm (M1-M6). These $\mathrm{CO}_{2}$ levels corresponded to $\left[\mathrm{H}^{+}\right]$from 7.94 to $35.48 \mathrm{nmol} \mathrm{L}{ }^{-1}$, equivalent to $\mathrm{pH}$ values ranging from $8.1-7.45$, (Supplementary Table 1 for day 12 values). Coastal Antarctic diatoms experience seasonal fluctuations in $\mathrm{pH}$ (7.99 8.20), where $\mathrm{pCO}_{2}$ is often oversaturated during winter and undersaturated in summer ${ }^{41}$. This natural variability makes predicting responses related to uptake of $\mathrm{CO}_{2}$ from atmospheric sources more difficult and as such, an extended gradient was chosen to cover a broader $\mathrm{pH}$ range than projected near future scenarios. The $\mathrm{CO}_{2}$ gradient experiment ran for 18 days, on a 19:5 h light:dark cycle (see Methods). Incubation $(24 \mathrm{~h})$ experiments to measure diatom silicification were conducted on samples taken from mesocosms on day 12, while cells were in exponential growth and macronutrient concentrations were replete (Supplementary Table 2). 
Silicification by the diatom community strongly and significantly diminished with increased acidity $\left({ }_{\text {Adj }} \mathrm{R}^{2}=0.801 ; \mathrm{F}_{1,16}=69.40 ; p<0.001 ;\right.$ Fig. 1a; Supplementary Table 3), with newly deposited silica as a proportion of the total biogenic silica (bSi; Supplementary Table 4) declining more than $60 \%$ between the 8.7 and $37.2\left[\mathrm{H}^{+}\right]$exposed treatments (Fig. 1a). This response co-occurred with a small, yet significant decline in photosynthetic health $\left(\mathrm{F}_{\mathrm{V}} / \mathrm{F}_{\mathrm{M}}\right)$ for the whole community $\left({ }_{\mathrm{Adj}} \mathrm{R}^{2}=0.495, \mathrm{~F}_{1,16}=\right.$ 17.65; $p<0.001$; Supplementary Fig. 1). Together, this suggests OA reduced the physiological status of at least some of the diatoms within this community.

The natural community consisted of $>35$ diatom taxa, including a diverse assemblage of large diatoms $(>20 \mu \mathrm{m})$ and an abundance of small $(<20 \mu \mathrm{m})$ diatoms, dominated by Fragilariopsis spp. (see 33)

Together, diatoms made up $\sim 20 \%$ of the initial plankton community, with heterotrophic ciliates and flagellates constituting $\sim 3 \%$. On day 12 , diatom contribution was much higher (33-79\%) with strong compositional differences in the diatom size fractions across the $\left[\mathrm{H}^{+}\right]$gradient, where under ambient $f \mathrm{CO}_{2}(\mathrm{pH} 8.06)$ large diatoms $(>20 \mu \mathrm{m})$ constituted $\sim 40 \%$ of the diatom community, compared to just $3 \%$ in the highest $f \mathrm{CO}_{2}$ treatment ( $\mathrm{pH} 7.43$; Fig. $1 \mathrm{~b}$; Supplementary Table 5), a response that is in agreement with other field manipulation experiments ${ }^{28,29}$. Heterotrophic plankton populations declined to constitute between $0.04-0.45 \%$ of the plankton community. Cell size and silica content control the efficiency of both sinking and energy transfer to higher trophic levels ${ }^{20}$. Thus, any shift towards small diatoms in response to high $\mathrm{CO}_{2}$ has the potential to extend the food chain, reduce the efficiency of energy transfer to higher trophic levels ${ }^{20}$ and reduce carbon export ${ }^{25}, 42$. In a previous study, a phytoplankton community shift toward small cells of just $3 \%$ was predicted to decrease carbon export by $8-9 \%{ }^{42}$.

\section{Diatoms lose their ballast}

Cell size, growth and silica content are strong determinants of diatom buoyancy and sinking velocity ${ }^{43}$ and therefore, the influence of any given diatom species on ocean biogeochemistry is a function of its growth strategy, size and frustule thickness ${ }^{20,25}$. Given the strong shift from larger to smaller diatoms, 
we wanted to see whether the drop in community silica production was the result of the decline in the proportion of large cells. Seven diatom taxa were studied using single-cell fluorescence analyses to resolve whether the declines in community silicification in the high $\mathrm{CO}_{2}$ treatments were due to the reduction in the abundance of the larger diatoms or a reduction in the rate of silica deposition by individual cells. Species were selected based on their presence in all mesocosms and confidence with which they could be identified. In three instances, due to difficulty in accurately identifying to species, taxa were grouped. Grouped taxa included Chaetoceros spp., non-specific discoid centric cells $(>20$ $\mu \mathrm{m})$ and chain forming Fragilariopsis cylindrus/curta. All remaining taxa were positively identified as individuals or chains of Thalassiosira antarctica, Stellarima microtrias, Proboscia truncata and Pseudo-nitzschia turgiduloides.

Elevated $\mathrm{CO}_{2}$ resulted in a decline in the average rate of silica deposition (Chaetoceros spp. 58\%, large discoid centrics 39\%, Fragilariopsis spp. 84\%, Proboscia truncata 45\%, Pseudo-nitzschia turgiduloides $84 \%$, Stellarima microtrias $59 \%$ and Thalassiosira antarctica 53\%), with significant negative relationships between silicification and $\left[\mathrm{H}^{+}\right]$in all species, except $P$. truncata (Fig. 2; Supplementary Table 3). These results were independent of any change in cell chlorophyll autofluorescence (Supplementary Fig. 2; Supplementary Table 3), confirming measurements of silica incorporation were unaffected by chlorophyll content. Reduction in silicification rates did not correlate with photosynthetic health $\left(\mathrm{F}_{\mathrm{V}} / \mathrm{F}_{\mathrm{M}}\right)$, which was more variable across species (Supplementary Fig. 3). $T$. antarctica, discoid centrics, S. microtrias and P. truncata responded negatively to high $\left[\mathrm{H}^{+}\right]$conditions (KS $<0.001$; Supplementary Table 6). Fragilariopsis spp. showed no response, while in Chaetoceros spp., $\mathrm{F}_{\mathrm{V}} / \mathrm{F}_{\mathrm{M}}$ increased $(\mathrm{KS}<0.05)$. The non-negative results correspond with previous OA studies on diatoms ${ }^{8,11}$, and overall these data suggest $\mathrm{CO}_{2}$-induced impacts on photosynthetic efficiency is speciesspecific.

137 In contrast to other environmental factors (e.g. nutrient availability) that indirectly affect silicification 138 by altering cell size and/or growth, our results show that seawater acidification directly affects the rate at which silica is deposited. While the specific growth rates of the key taxa showed negative 
relationships with increasing $\left[\mathrm{H}^{+}\right]$in four cases (Supplementary Fig. 4; Supplementary Table 3), we

141 found a non-linear association between reduced silicification and declining growth rates (Fig. 3a),

142 indicating that silica incorporation was affected at a lower threshold of acidification than growth. This contrasts with the inverse relationship between growth rate and silicification that is typically observed in diatoms ${ }^{19}$. The cell volume of diatoms in this study ranged over four orders of magnitude (Supplementary Fig. 5) and consistent with previous studies ${ }^{26,44}$, showed a significant relationship between cell surface area and silicification $\left({ }_{\text {Adj }} \mathrm{R}^{2}=0.763, \mathrm{~F}_{1,5}=20.30 ; p=0.0064\right)$. However, except for Fragilariopsis spp. $(<20 \mu \mathrm{m})$, acidification had no negative effect on mean cell surface area (Fig. $3 b$ ), indicating that the changes observed in silicification are unlikely to be a result of altered growth or cell size with acidity. A complete mechanistic understanding of the direct effect of $\mathrm{CO}_{2}$ on diatom silicification is lacking. One study however, showed that while the influx of silicic acid was unchanged by low $\mathrm{pH}$, silica efflux from the cell was enhanced. As such, the diminished silicification under high $f \mathrm{CO}_{2}$ may be attributed to increased silica efflux from the cell ${ }^{137}$ where a change in the influx to efflux ratio results in a change in the mass balance of Si quota of the cell ${ }^{37}$. Indirect effects from nutrient colimitation or potential changes to trace metal chelation under high $\mathrm{pCO}_{2}{ }^{45}$ could also provide some explanation for altered silicification, however the use of near shore waters meant that iron was unlikely to be limiting in this study. Overall, these data reveal the potential for frustule thinning through OAinduced reductions in silica deposition by diatoms. This consequent reduction in ballasting of cells is likely to reduce cell sinking rates and alter export flux of silicon and carbon.

To rank species importance with respect to silica production, we determined each species contribution as a function of its relative abundance and silica content per cell ${ }^{25,44}$. The diatoms contributing the most to new silica precipitation were the large discoid centric group and $S$. microtrias. Their combined contribution was $>80 \%$, followed by the heavily silicified pennate diatom Fragilariopsis sp.

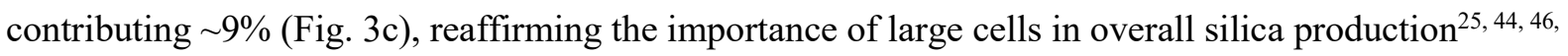
${ }^{47}$. Interestingly, despite being the most abundant of the species studied, Chaetoceros spp. was the third lowest contributor to new silica. P. truncata, the third largest species (Supplementary Fig. 5) constituting $\sim 12 \%$ of the large diatom community, contributed $<5 \%$ to newly precipitated silica. It was 
also the only species that showed no response to acidification, maintaining abundance, growth rate and silicification irrespective of $\left[\mathrm{H}^{+}\right]$. Despite variability among taxa, elevated $\mathrm{CO}_{2}$ did not greatly alter their relative silica contributions with the exception of Fragilariopsis spp. $(>20 \mu \mathrm{m})$ whose relative contribution declined to $<<1 \%$ (Fig. 3c, inset), due to a significant OA-induced decline in both the rate of silicification and overall cell abundance. Importantly, the two taxonomic groups that made the greatest contribution to community silicification (discoid centrics and S. microtrias) underwent some of the strongest declines in growth rate and abundance. This alarming loss of significant silicifiers strongly refutes the idea that $\mathrm{OA}$ is unlikely to affect diatoms negatively, instead emphasising a need to better understand the responses of diatoms to ocean change.

\section{A new threat from OA}

We calculated the mean effect size of key diatom responses to $\left[\mathrm{H}^{+}\right]$, highlighting for the first time that increased $\left[\mathrm{H}^{+}\right]$exerts a rapidly increasing negative effect on silicification (Fig. 4); a hitherto unrecognised effect of OA. Importantly, our data showed that the onset of reduced silicification occurs at much lower $\mathrm{pH}$ levels than $\mathrm{OA}$-induced changes in the other functional traits, growth or productivity. Here, newly precipitated silica declined significantly at $\mathrm{pH} 7.84$ (M3), a pH threshold that we expect to exceed in Antarctica before the end of the century ${ }^{48}$. Given the depth-dependent fluctuations in $p \mathrm{CO}_{2}$ in Antarctic waters ${ }^{41}$ and accelerated $\mathrm{pH}$ decline ${ }^{48}$, it will not require much anthropogenic enhancement of $\mathrm{CO}_{2}$ before levels will rise above those shown to affect diatom silica deposition. In contrast with the positive effects generally reported by previous studies ${ }^{11,27,32}$, we saw no overall effect on diatom photosynthesis, and no effect on growth until the highest $\left[\mathrm{H}^{+}\right]$, suggesting that Antarctic diatom growth and photosynthesis at the community level are not significantly influenced by lowered $\mathrm{pH}$. Instead, if these data accurately represent future diatom physiologies, the changes to frustule density, measured here as reduced silicification rate, have the potential to strongly diminish the grazing resistance ${ }^{21}$ and sinking capacity ${ }^{43,49}$ of cells, undoubtedly altering the efficacy of the ocean biological carbon pump. 
In this work, we uncover the effect of OA on diatom silicification rates and confirm the importance of species composition in influencing marine biogeochemistry ${ }^{25}$. 26 . This study reveals how OA can exert a large influence over the silicification of diatoms by changing community composition and the individual rates at which diatom cells deposit silica in their frustules. While our findings are consistent with previous studies that have highlighted the central role of large diatoms in community silica formation ${ }^{44,47,49}$, here we place them in the context of future changes in ocean acidity, and reveal significant $\mathrm{CO}_{2}$-induced losses in silica incorporation, the process that underpins carbon export potential.

Silicon and carbon export are strongly influenced by diatom growth strategy ${ }^{25}$, where bloom forming diatoms, often lightly silicified, tend to export ample carbon but minimal silica, whereas strongly silicified species such as large centric diatoms, often subject to lower grazing pressure, make efficient vectors for silica export ${ }^{20,25,49}$. Here, using single cell analyses, we were able to disentangle the influence of individual species from that of the whole community, partitioning $\mathrm{CO}_{2}$-induced changes in growth, photosynthesis and silicification amongst the silicate and carbon exporters. In doing so, we revealed negative impacts in more than one of these functional traits for several key taxa. Of note were the heavy losses of the important silicifier $S$. microtrias and bloom forming Chaetoceros spp., as well as the significant reduction in growth and silicification of Fragilariopsis spp.. Members of the genus Fragilariopsis are some of the most abundant diatoms in Antarctic waters and contribute greatly to blooms that underpin phytoplankton productivity in these waters ${ }^{50}$. Considering ocean acidification affected both heavy silicifiers and bloom formers, our results emphasise prospective changes to the ecological role and influence of important and frequently dominant taxa for the Antarctic marine ecosystem. Our results have started to reveal how shifts in diatom assemblages and individual rates of silicification may alter the effectiveness of silicon and carbon cycling, as well as food web dynamics.

217 Understanding the influence of a shift towards smaller and less silicified diatoms on ocean processes is 218 not easily realised. Thinner frustules have less ballast, which is likely to reduce sinking rates ${ }^{20,25}$. The 
slower draw-down of silicic acid, as a result of elevated $\mathrm{CO}_{2}$ concentrations, could also extend the duration of diatom blooms. Extended diatom bloom duration combined with lower levels of silicification, and therefore reduced protection against predation, may increase grazing in surface waters, leading to higher remineralisation in the euphotic zone, which would also reduce vertical flux. Conversely, increased grazing could boost faecal pellet production enhancing silica and carbon export fluxes. Regardless of the prevailing processes, altered diatom silica production (either via selection for smaller cells or reduced silicification) will ultimately affect surface ocean silicic acid concentrations ${ }^{26 \text {, }}$ ${ }^{49}$, and with the Sub-Antarctic mode water as a conduit for dissolved nutrients to the global ocean ${ }^{51}$, any significant changes in Antarctic diatom communities has the potential to influence nutrient stoichiometry, primary productivity and export at lower latitudes ${ }^{52}$.

The future of oceanic carbon sequestration remains ambiguous because of the uncertainties associated with potential changes to the biological carbon pump $^{25}$. Current predictions on climate driven changes to ocean productivity are incomplete, because many of the effects of these environmental changes on phytoplankton groups, the interactions among lower trophic levels and the feedbacks to climate change are poorly understood. The effect of $\mathrm{OA}$ on species selection and silicification and the consequences for carbon export may be mediated by exposure to coincident environmental stresses imposed by changing climate $\mathrm{e}^{53-56}$ or higher trophic interactions. Yet, this study establishes silicification is sensitive to OA, with potentially crucial consequences for both trophodynamics and elemental cycling in Antarctic coastal waters and beyond.

\section{Methods}

\section{Mesocosm set up and carbonate chemistry}

Mesocosm set up and conditions were as described previously ${ }^{29}$ 33. Briefly, a six-level, gradient experiment was conducted on a natural nearshore Antarctic microbial community using seawater collected from an ice-free area amongst broken fast ice, approx. $1 \mathrm{~km}$ offshore of Davis Station, Antarctica $\left(68^{\circ} 35^{\prime} \mathrm{S}, 77^{\circ} 58^{\prime} \mathrm{E}\right)$ on the $19^{\text {th }}$ of November 2014 . Water from a header tank was 
transferred to simultaneously fill six, acid washed, mesocosm tanks $(650 \mathrm{~L})$ via a Teflon lined tube

246 fitted with a $200 \mu \mathrm{m}$ in-line filter, to remove metazooplankton. Mesocosms were housed in a 247 temperature-controlled shipping container maintained at $0.0^{\circ} \mathrm{C} \pm 0.5^{\circ} \mathrm{C}$. Mesocosms were stirred continuously by a central auger $(15 \mathrm{rpm})$ for gentle mixing, covered with an acrylic air tight lid and acclimated over five days to increasing $\mathrm{CO}_{2}$ while irradiance was kept low $\left(0.8 \pm 0.2 \mu\right.$ mol photons $\mathrm{m}^{-}$ $\left.{ }^{2} \mathrm{~s}^{-1}\right)$. Once target $\mathrm{CO}_{2}$ levels were reached in all six mesocosms $(343,506,634,953,1140,1641 \mu \mathrm{atm})$, these levels were maintained via daily adjustment. Following $\mathrm{CO}_{2}$ acclimation, light was incrementally increased (days 5-8) to $89 \pm 16 \mu \mathrm{mol}$ photons $\mathrm{m}^{-2} \mathrm{~s}^{-1}$ on a 19:5 h light:dark cycle. Samples for macronutrient concentrations were obtained from each mesocosm on day 12, filtered through $0.45 \mu \mathrm{m}$ cellulose ester filters (Millipore), frozen at $-20^{\circ} \mathrm{C}$ and analysed as described previously ${ }^{29}$. In the case of silicic acid, inaccuracies due to non-quantitative depolymerisation of silicic acid during thawing cannot be ruled out.

257

To generate the above gradient in carbonate chemistry, five of the mesocosms were amended with different volumes of filtered seawater saturated with $\mathrm{CO}_{2}$. To control for physical disturbance and dilution from $\mathrm{CO}_{2}$-rich seawater additions, non-enriched seawater was added to one mesocosm, which remained at ambient $\mathrm{pCO}_{2}$ levels (M1). Carbonate chemistry speciation was determined daily by measurements of $\mathrm{pH}$ (on the total scale) and dissolved inorganic carbon (DIC). The former was measured using the indicator dye m-cresol purple on a GBC UV-vis 916 spectrophotometer in a $10 \mathrm{~cm}$ temperature-controlled $\left(25^{\circ} \mathrm{C}\right)$ cuvette $^{57}$. DIC was measured on an Apollo SciTech AS-C3 by infra-red absorption and calibrated against certified reference material batch $\mathrm{CRM} 127^{58}$. For details on $\mathrm{CO}_{2}$ manipulations, analytical procedures and calculations (see 33). Hydrogen ion equivalent concentrations $\left(\left[\mathrm{H}^{+}\right]\right)$were calculated from the total scale $\mathrm{pH}$.

Diatom community structure

Samples for community structure and abundance were collected from each mesocosm on days 1, 3, 5, 
samples $(960 \mathrm{~mL})$ were serially concentrated via sedimentation aspiration of the supernatant until approx. $20 \mathrm{~mL}$ remained (see 31 for details). Between $2-10 \mathrm{~mL}$ of concentrated-fixed sample was placed in an Utermöhl cylinder (Hydro-Bios, Keil) and cells allowed to settle overnight. To capture both small and large cells, a stratified counting procedure was used, where all cells greater than $20 \mu \mathrm{m}$ were identified and quantified at $200 \times$ magnification, while those less than $20 \mu \mathrm{m}$ were assessed at $400 \times$ magnification. Initial in-line filtration $(200 \mu \mathrm{m})$ of seawater to remove grazers likely removed some of the larger diatom species, as few exceptionally large taxa, such as Corethron and Thalassiothrix were found. Diatom counts from days 8-16 were used to determine specific growth rate $(\mu)$ for each diatom species or taxonomic group accordingly. Day 18 was excluded as community counts started to decline ${ }^{31}$ with nutrients becoming limitating ${ }^{33}$. Abundance of each taxon on day 12 was used to calculate relative abundance (Fig. 3c; Supplementary Table 5), but in the three cases where counts were anomalous on day 12 due to poor sampling, counts were estimated by extrapolation from the growth curve.

\section{Sampling and silicification experiments}

To investigate diatom silicification rates, water samples were collected from each mesocosm during exponential phase (day 12: see 31). Samples were transferred in triplicate into $125 \mathrm{~mL}$ acid-cleaned polycarbonate bottles and incubated with the fluorescent dye 2-(4-pyridyl)-5-((4-(2dimethylaminoethylaminocarbamoyl)methoxy)phenyl)oxazole (PDMPO; LysoSensor Yellow/Blue DND-160 from ThermoFisher Scientific, Australia). Cells were incubated in the presence of the dye ( $0.125 \mu \mathrm{M}$, final concentration), as well as an unamended control (to quantify background fluorescence) for $24 \mathrm{~h}$ under experimental temperature and light conditions. Following incubation, six $1.8 \mathrm{~mL}$ aliquots from each bottle were fixed with glutaraldehyde ( $2 \%)$ and flash frozen in liquid $\mathrm{N}_{2}$ for cell-specific PDMPO incorporation using fluorescence microscopy. To determine biogenic silicate (bSi) production of the whole-community using bSi measurements and PDMPO incorporation (a proxy for bSi production $)^{60}, 100 \mathrm{~mL}$ from each of the remaining incubation bottles was filtered onto a $47 \mathrm{~mm}$ polycarbonate filter $(0.6 \mu \mathrm{m}$; Millipore, Bayswater, Australia). To remove residual and unbound 
PDMPO, filters were rinsed using seawater $(0.2 \mu \mathrm{m}$ filtered $)$ before being stored at $-20{ }^{\circ} \mathrm{C}$ until later analysis in the laboratory (within 12 months).

The fluorescent $\mathrm{pH}$ indicator PDMPO has silica-philic properties that make it an excellent probe for quantifying and visualising silica deposition in living diatoms ${ }^{44,59-62}$. It has been used successfully in diatom research to resolve silica precipitation and production rates $^{44,61}$, as well as probe the effects of nutrient limitation on silicification ${ }^{47}$. Given it's a $\mathrm{pH}$ probe and in the context of this study, it is important to note there is no effect of extraneous $\mathrm{pH}$ between 4.5 and 9.5 on the binding mode of the dye $^{63}$. Furthermore, any $\mathrm{pH}$-dependent shifts in emission maxima previously shown are negligible within the $\mathrm{pH}$ range (8.06-7.43) of this study ${ }^{59}$. However, external $\mathrm{pH}$ could affect the speciation of the PDMPO dye (protonated versus non-protonated) and thus its ability to diffuse through cell membranes. The pKa of the first protonation of PDMPO is unknown, but has been estimated at $6.78^{59}$. Using this estimate, there would be a potential increase in the protonated fraction of PDMPO of $\sim 13 \%$ from the lowest to the highest $f \mathrm{CO}_{2}$, resulting in an equivalent reduction in influx of PDMPO and thus in the PDMPO incorporation per silica. Therefore, assuming a fixed incorporation efficiency, there could be a $\sim 13 \%$ underestimation of silica incorporated at the lowest $\mathrm{pH}$. Previous work has shown the fluorescence intensity of PDMPO is related directly to the amount of precipitated silica, with an interspecies or community variability rate of $\sim 20 \%{ }^{60}$. Our data displayed differences exceeding this variability both between species (with fluorescence ranging three orders of magnitude) and amongst our $\mathrm{CO}_{2}$ treatments (declines of $39-84 \%$ ) in response to lowered $\left[\mathrm{H}^{+}\right]$, reinforcing the importance of these species-specific quantitative losses in silica precipitation with acidification.

\section{Whole community PDMPO and BSi determination}

Post-sampling, the amount of PDMPO incorporated was analysed using established methods ${ }^{45}$. Briefly, diatom frustules were initially solubilised via a hot-alkaline-digest to release frustule-bound PDMPO before being analysed via a scanning UV-spectrofluorometer (50 Bio; Cary, Agilent Technologies, U.S.A.) set to excite at $375 \mathrm{~nm}$ and emission was detected at $530 \mathrm{~nm}$. Samples were compared against 
a standard curve $\left(\mathrm{R}^{2}=0.995\right)$ made with $125 \mu \mathrm{M}$ PDMPO solution that was prepared using the digestion (NaOH-HCl) matrix. We used the recommended ratio of $2916 \mathrm{~mol} \mathrm{bSi}$ per mol $\mathrm{PDMPO}^{64}$ in order to convert quantitative PDMPO incorporation to bSi production (processes which are proportionally equal on a mol:mol basis in both monoculture and natural diatom communities $)^{60}$. The remaining digest was used for colorimetric analysis of reactive silicate ${ }^{64,65}$. Absorbance was measured at $810 \mathrm{~nm}$ (Cary Eclipse, Agilent Technologies, U.S.A.) and compared against a standard curve $\left(\mathrm{R}^{2}=0.997\right)$ made with sodium metasilicate stock solution.

\section{Species-specific silicification by fluorescence microscopy}

For cell-specific silicification of diatoms $>20 \mu \mathrm{m}$, two of the $1.8 \mathrm{~mL}$ frozen aliquots from each replicate ( $n=3$ ), were filtered onto $25 \mathrm{~mm}, 1.2 \mu \mathrm{m}$ black polycarbonate membranes (Millipore, Bayswater, Australia) under gentle vacuum and the filters mounted on a glass slide with a drop of immersion oil.

A glass coverslip was applied and sealed with clear nail varnish. Cells were imaged using a Nikon fluorescence microscope at a total of $200 \times$ magnification, systematically scanning the entire filter collecting images of all seven identifiable taxa in DAPI (PDMPO) and autofluorescence (chl $a$ ). We quantified the relative amount of newly precipitated silica per cell based on the incorporation of PDMPO into individual frustules after $24 \mathrm{~h}$, and then compared the relative amounts of newly precipitated silica by each species/group across experimental $\left[\mathrm{H}^{+}\right]$treatments.

Each cell image was analysed for total PDMPO fluorescence using custom-made macros in the ImageJ software $^{66}$. Briefly, each cell was horizontally or vertically aligned and cropped to ensure minimal background area, after which any interfering fluorescence from other objects in the image was removed manually by setting the respective area to zero pixel intensity. We measured background fluorescence in all four corners around the cell and the average background +1 standard deviation was subtracted from the whole image to remove background fluorescence, after which the total fluorescence of the image was recorded as total pixel intensity. In some cases, it was not feasible to separate two or more closely positioned cells, in which cases the number of cells was recorded and the total fluorescence of 
the image was divided by the number of cells to determine fluorescence per cell. Images with more than one cell were recorded as one data point in subsequent analyses.

The photophysiological condition of diatom cells were assessed via single-cell chlorophyll $a$ fluorescence. Samples were collected from three mesocosms (M1, M4, M6) and loaded into a flow cell with a $1 \mathrm{~mm}$ gasket spacer (Bioptech, USA). Variable chlorophyll $a$ fluorescence measurements were made on randomly selected individual diatoms (generally $>20 \mu \mathrm{m}$, or else long Chaetoceros chains) within each population $(n=60-122$ individuals) using a pulse amplitude modulated fluorometer (Imaging PAM IMAG-K4, Walz GmbH, Effeltrich, Germany) mounted on a compound microscope (Axiostar plus, Zeiss, Germany). Measurements were made at $200 \times$ magnification employing blue excitation light (440 nm) and collected using the Imaging Win software (V2.32 FW Multi RGB; Walz $\mathrm{GmbH}$, Effeltrich, Germany). After 10 min dark-adaptation, minimum fluorescence $\left(\mathrm{F}_{\mathrm{O}}\right)$ was recorded before application of a saturating pulse of light (saturating pulse width $=0.8 \mathrm{~s}$; saturating pulse intensity $=10$; using the Special SP-routine), where maximum fluorescence $\left(\mathrm{F}_{\mathrm{M}}\right)$ was determined. From these two parameters $\mathrm{F}_{\mathrm{V}} / \mathrm{F}_{\mathrm{M}}$ was calculated as $\left(\mathrm{F}_{\mathrm{M}}-\mathrm{F}_{\mathrm{O}}\right) / \mathrm{F}_{\mathrm{M}}$. All measurements were made in a cold-room set at $0^{\circ} \mathrm{C}$.

The six level $f \mathrm{CO}_{2}$ gradient approach meant that our data could be analysed using a regression model, allowing us to identify functional relationships between our $f \mathrm{CO}_{2}$ treatment and our response variables. Gradient designs have been shown to consistently outperform replicated designs in ecology ${ }^{67}$. They are more effective at uncovering underlying responses patterns to environmental drivers ${ }^{39,67,68}$, improving interpolation potential and generally deliver more useful quantitative information for models ${ }^{40}$. For these reasons, gradient designs are a statistically powerful way to investigate ecological responses to continuous environmental drivers ${ }^{67}$. 
375 Instead of $\mathrm{pH}$, which follows a log scale, we used proton concentration $\left[\mathrm{H}^{+}\right]$to provide a linear scale

376 with which to analyse our response variables. Species-specific responses to $f \mathrm{CO}_{2}$, were visualised using 377 box plots. After verifying normality and the residuals for homoscedasticity, we used model 1 linear 378 regression $( \pm 95 \% \mathrm{CI})$ to determine a significant relationship between our measured parameters and $379 f \mathrm{CO}_{2}$, with significant differences in regressions assessed via ANOVA. Species-specific $\mathrm{F}_{\mathrm{V}} / \mathrm{F}_{\mathrm{M}}$ were analysed using a 2-sided Kolmogorov-Smirnov test and differences considered significant at $P<0.05$.

\section{Data availability}

The data that support these findings are available from the Australian Antarctic Data Centre (doi:10.26179/5c3e745a9b071).

Code availability

No custom code or mathematical algorithm was used in this study.

\section{End notes}

390

All correspondence and request for materials pertaining to this paper should be directed to the author for correspondence Petrou K (Katherina.Petrou@uts.edu.au).

\section{Acknowledgements}

394 The work was supported by Australian Antarctic Science project AAS 4026 from the Australian Antarctic Division (AAD), samples were imported under permit IP13019928. We are grateful to AAD technical support for their assistance and support in designing and equipping the mesocosm facility and the Davis Station expeditioners in the summer of 2014/2015. 
399 Author contributions

400 Conceptualisation: KP; investigation: KP, KGB, DAN, AMH, KGS, ATD; methodology KP, KGB;

401 formal analysis, KP, DAN; visualisation: KP, DAN; writing - original draft preparation: KP; Writing 402 - review and editing: KP, KGB, DAN, AMH, KGS, ATD; funding acquisition, resources: KP, ATD.

403 


\section{References}

1. Khatiwala, S., Primeau, F. \& Hall, T. Reconstruction of the history of anthropogenic CO2 concentrations in the ocean. Nature. 462, 346-349 (2009).

2. Sabine, C.L., Feely, R.A., Gruber, N., Key, R.M., Lee, K., Bullister, J.L., Wanninkhof, R., Wong, C.S.L., Wallace, D.W., Tilbrook, B. \& Millero, F.J. The oceanic sink for anthropogenic CO2. Science. 305, 367-371 (2004).

3. Orr, J.C., Fabry, V.L., Aumont, O., Bopp, L., Doney, S.C., Feely, R.A., Gnanadesikan, A., Gruber, N., Ishida, A., Joos, F., \& Key, R.M. Anthropogenic ocean acidification over the twenty-first century and its impact on calcifying organisms. Nature. 437, 681 (2005).

4. Riebesell, U., Zondervan, I., Rost, B., Tortell, P.D., Zeebe, R.E. \& Morel, F.M.M. Reduced calcification in marine plankton in response to increased atmospheric CO2. Nature. 407, 634 637 (2000).

5. Fabry, V.J. Marine calcifiers in a high-CO2 ocean. Science. 320, 1020-1022 (2008).

6. Doney, S. C., Fabry, V.J., Feely, R.A., \& Kleypas, J.A. Ocean Acidification: The Other $\mathrm{CO}_{2}$ Problem. Annual Review of Marine Science. 1, 169-192 (2009).

7. Levitan, I., Rosenberg, G., Setlik, I., Setlikova, E., Grigel, J., Klepetar, J., Prasil, O. \& BermanFrank, I. Elevated $\mathrm{CO} 2$ enhances nitrogen fixation and growth in the marine cyanobacterium Trichodesmium. Global Change Biology. 13, 1-8 (2007).

8. Tortell, P., Payne, C., Li, Y., Trimborn, S., Rost, B., Smith, W.O., Riesselman, C., Dunbar, R.B., Sedwick, P.N. \& DiTullio, G.R. CO2 sensitivity of Southern Ocean phytoplankton. Geophysical Research Letters 35, (2008).

9. Wu, Y., Gao, K. \& Riebesell, U. CO2-induced seawater acidification affects physiological performance of the marine diatom Phaeodactylum tricornutum. Biogeosciences. 7, 2915-2923 (2010). doi:10.5194/bg-7-2915-2010

10. Schaum, E., Rost, B., Millar, A.J. \& Collins, S. Variation in plastic responses of a globally distributed picoplankton species to ocean acidification. Nature Climate Change 3, 298-302 (2013).

11. Wu, Y., Campbell, D.A., Irwin, A.J., Suggett, D.J. \& Finkel, Z.V. Ocean acidification enhances the growth rate of larger diatoms. Limnology \& Oceanography 59, 1027-1034 (2014). doi:10.4319/lo.2014.59.3.1027

12. Dutkiewicz, S., Morris, J.J., Follows, M.J., Scott, J., Levitan, O., Dyhrman, S.T. \& BermanFrank, I. Impact of ocean acidification on the structure of future phytoplankton communities. Nature Climate Change 5, 1002 (2015). doi:10.1038/nclimate2722

13. Mackey, K.R.M., Morris, J.J., Morel, F.M.M. \& Kranz, S.A. Response of Photosynthesis to Ocean Acidification. Oceanography 28, 74-91 (2015).

14. Riebesell, U., Gattuso, J-P., Thingstad, T.F. \& Meddleburg, J.J. Arctic ocean acidification: pelagic ecosystem and biogeochemical responses during a mesocosm study. Biogeosciences 10, 5619-5626 (2013). 
15. Sala, M.M., Aparicio, F.L., Balagué, V., Boras, J.A., Borrull, E., Cardelús, C., Cros, L., Gomes, A., López-Sanz, A. \& Malits, A. Contrasting effects of ocean acidification on the microbial food web under different trophic conditions. Ices Journal of Marine Science. 73, 670-679 (2015).

16. Burkhardt, S., Riebesell, U. \& Zondervan, I. Effects of growth rate, $\mathrm{CO} 2$ concentration, and cell size on the stable carbon isotope fractionation in marine phytoplankton. Geochimica et Cosmochimica Acta. 63, 3729-3741 (1999). doi:https://doi.org/10.1016/S0016$\underline{\text { 7037(99)00217-3 }}$

17. Tortell, P.D., DiTullio, G., Sigman, D.M. \& Morel, F.M.M. CO2 effects on taxonomic composition and nutrient utilization in an Equatorial Pacific phytoplankton assemblage. Marine Ecology Progress Series. 236, 37-43 (2002).

18. Nelson, D.M., Treguer, P., Brzezinski, M.A., Leynaert, A. \& Queguiner, B. Production and dissolution of biogenic silica in the ocean: Revised global estimates, comparison with regional data and relationship to biogenic sedimentation. Global Biogeochemical Cycles. 9, 359-372 (1995).

19. Martin-Jezequel, V., Hildebrand, M. \& Brzezinski M.A. Silicon metabolism in diatoms: Implications for growth. Journal of Phycology. 36, 821-840 (2000).

20. Smetacek, V. Diatoms and the ocean carbon cycle. Protist. 150, 25-32 (1999).

21. Hamm, C.E., Merkel, R., Springer, O., Jurkiojc, P., Maier, C., Prechtel, K. and Smetacek, V. Architechture and material properties of diatom shells provide effective mechanical protection. Nature. 421, 841-843 (2003).

22. Buesseler, K.O. The decoupling of production and particle export in the surface ocean. Global Biogeochemical Cycles. 12, 297-310 (1998).

23. Dugdale, R.C., \& Wilkerson, F.P. Silicate regulation of new production in the equatorial Pacific upwelling. Nature. 391, 279 (1998).

24. Agusti, S., Gonzalez-Gordillo, J., Vaqué, D., Estrada, M., Cerezo, M.I., Salazar G., Gasol, M.J. $\&$ Duarte, C.M. Ubiquitous healthy diatoms in the deep sea confirm deep carbon injection by the biological pump. Nature Communications. 6, 7608 (2015).

25. Tréguer, P., Bowler, C., Moriceau, B., Dutkiewicz, S., Gehlen, M., Aumont, O., Bittner, L., Dugdale, R., Finkel, Z., Iudicone, D., Jahn, O., Guidi, L., Lasbleiz, M., Leblanc, K., Levy, M. $\&$ Pondaven, P. Influence of diatom diversity on the ocean biological carbon pump. Nature Geoscience. 11, 27-37 (2018). doi:10.1038/s41561-017-0028-x

26. Baines, S.B., Twining, B.S., Brzezinski, M.A., Nelson, D.M. \& Fisher, N.S. Causes and biogeochemical implications of regional differences in silicification of marine diatoms. Global Biogeochemical Cycles 24, GB4031 (2010).

27. Bach, L.T., Hernández-Hernández, N., Taucher, J., Spisla, C., Sforna, C., Riebesell, U. \& Arístegui, J. Effects of Elevated CO2 on a Natural Diatom Community in the Subtropical NE Atlantic. Frontiers in Marine Science, 6 (75). doi:10.3389/fmars.2019.00075 (2019).

28. Tatters, A.O., Roleda, M.Y., Schnetzer, A., Fu, F., Hurd, C.L., Boyd, P.W., Caron, D.A., Lie, A.A.Y., Hoffmann, L.J. \& Hutchins, D.A. Short- and long-term conditioning of a temperate 
marine diatom community to acidification and warming. Phil Trans R Soc B. 368, 20120437 (2013).

29. Davidson, A.T., McKinlay, J., Westwood, K., Thomson, P. G., van den Enden, R., de Salas, M., Wright, S., Johnson, R., \& Berry, K. Enhanced CO2 concentrations change the structure of Antarctic marine microbial communities. Marine Ecology Progress Series. 552, 93-113 (2016).

30. Schulz, K.G., Bach, L.T., Bellerby, R., Bermudez, R., Budenbender, J., Boxhammer, T., Czerny, J., Engel, A., Ludwig, A., Meyerhofer, M., Larsen, A., Paul, A., Sswat, M., \& Riebesell, U. Phytoplankton blooms at increasing levels of atmospheric carbon dioxide: experimental evidence for negative effects on prymnesiophytes and positive on small picoeukaryotes. Frontiers in Marine Science. 4, 64. (2017).

31. Hancock, A.M., Davidson, A.T., McKinley, J., McMinn, A., Schulz, K.G., \& van den Enden, R. Ocean acidification changes the structure of an Antarctic coastal protistan community. Biogeosciences Discussions. 15, 2393-2410 (2018). doi.org/10.5194/bg-2017-224.

32. Riebesell, U. \& Tortell, P.D. Effects of ocean acidification on pelagic organisms and ecosystems. Ocean acidification. (2011) 99-121.

33. Deppeler, S., Petrou, K., Schulz, K.G., Westwood, K., Pearce, I., McKinlay, J., \& Davidson, A. Ocean acidification of a coastal Antarctic marine microbial community reveals a critical threshold for $\mathrm{CO}_{2}$ tolerance in phytoplankton productivity. Biogeosciences. 15, 209 (2018).

34. Westwood, K., Thomson, P., van den Enden, R., Maher, L., Wright, S. \& Davidson, A. Ocean acidification impacts primary and bacterial production in Antarctic coastal waters during austral summer. Journal of Experimental Marine Biology and Ecology. 498, 46-60 (2018).

35. Milligan, A.J. \& Morel, F.M. A proton buffering role for silica in diatoms. Science. 297, 18481850 (2002).

36. Hervé, V., Derr, J., Douady, S., Quinet, M., Moisan, L., Lopez, P.J. Multiparametric analyses reveal the $\mathrm{pH}$-dependence of silicon biomineralization in diatoms. PLOS One. 7, e46722 (2012).

37. Milligan, A.J., Varela, D.E., Brzezinski, M.A. \& Morel, F.M.M. Dynamics of silicon metabolism and silicon isotopic discrimination in a marine diatom as a function of $\mathrm{pCO}_{2}$. Limnology and Oceanography. 49, 322-329 (2004).

38. Sugie, K. \& Yoshimura, T. Effects of high CO2 levels on the ecophysiology of the diatom Thalassiosira weissflogii differ depending on the iron nutritional status. ICES Journal of Marine Science. 73, 680-692 (2016). doi:10.1093/icesjms/fsv259

39. Riebesell, U. \& Gattuso J-P. Lessons learned from ocean acidification research. Nature Climate Change. 5, 12-14 (2015).

40. Havenhand, J., Dupont, S. \& Quinn, G.P. Designing ocean acidification experiments to maximise inference. In. Riebesell, U., Fabry, V.J., Hansson, L., Gattuso, J-P. Eds. Guide to best practices for ocean acidification research and data reporting (2010). Luxembourg: Publications Office of the European Union.

41. Roden, N.P., Shadwick, E.H., Tilbrook, B. \& Trull, T.W. Annual cycle of carbonate chemistry and decadal change in coastal Prydz Bay, East Antarctica. Marine Chemistry. 155, 135-147 (2013). doi.org/10.1016/j.marchem.2013.06.006 
42. Dutkiewicz, S., Scott, J.R. \& Follows, M.J. Winners and losers: Ecological and biogeochemical changes in a warming ocean. Global Biogeochemical Cycles. 27, 463-477 (2013).

43. Miklasz, K.A. \& Denny, M.W. Diatom sinking speeds: improved predictions and insight from a modified Stoke's law. Limnology \& Oceanography. 55, 2513-2525 (2010).

44. McNair, H.M., Brzezinski, M.A., Till, C.P. \& Krause, J.W. Taxon-specific contributions to silica production in natural diatom assemblages. Limnology \& Oceanography. 63,1056-1075 (2018).

45. Shi, D., Xu, Y., Hopkinson, B.M. \& Morel, F.M.M. Effect of Ocean Acidification on Iron Availability to Marine Phytoplankton. Science, 327, 676-679 (2010).

46. Villareal, T.A., Altabet, M.A. \& Culver-Rymsza, K. Nitrogen transport by vertically migrating diatom mats in the North Pacific Ocean. Nature. 363, 709 (1993).

47. Durkin, C.A., Marchetti, A., Bender, S.J., Truong, T., Morales, R., Mock, T. \& Armbrust, E.V. Frustule-related gene transcription and the influence of diatom community composition on silica precipitation in an iron-limited environment. Limnology \& Oceanography. 57, 1619-1633 (2012).

48. McNeil, B. \& Matear, R. Southern Ocean acidification: a tipping point at 450-ppm atmospheric CO2. Proceedings of the National Academy of Sciences. 105,18860-18864 (2008).

49. Assmy, P., Smetacek, V., Montresor, M., Klaas, C., Henjes, J., Strass, V.H., Arrieta, J.M., Bathmann, U., Berg, G.M., Breitbarth, E. \& Cisewski, B. Thick-shelled, grazer-protected diatoms decouple ocean carbon and silicon cycles in the iron-limited Antarctic Circumpolar Current. Proceedings of the National Academy of Sciences. 110, 20633-20638 (2013).

50. Kang, S. \& Fryxell, G. Fragilariopsis cylindrus (Grunow) Krieger: The most abundant diatom in water column assemblages of Antarctic marginal ice-edge zones. Polar Biology. 12, 609-627 (1992).

51. Matsumoto, K., Sarmiento, J.L. \& Brzezinski, M.A., Silicic acid leakage from the Southern Ocean: A possible explanation for glacial atmospheric pCO2. Global Biogeochemical Cycles, 16, 5-1 (2002).

52. Boyd, P.W. Physiology and iron modulate diverse responses of diatoms to a warming Southern Ocean. Nature Climate Change 9,148-152 (2019).

53. Boyd, P.W., Lennartz, S.T., Glover, D.M. \& Doney, S.C. Biological ramifications of climatechange-mediated oceanic multi-stressors. Nature Climate Change. 5, 71-79 (2014).

54. Petrou, K., Kranz, S.A., Trimborn, S., Hassler, C.S., Ameijeiras, S.B., Sackett, O., Ralph, P.J., Davidson, A.T. Southern Ocean phytoplankton physiology in a changing climate. Journal of Plant Physiology, 203, 135-150 (2016).

55. Boyd, P.W., Dillingham, P.W., McGraw, C.M., Armstrong, E.A., Cornwall, C.E., Feng, Y.-Y., Hurd, C.L., Gault-Ringold, M., Roleda, M.Y., Timmins-Schiffman, E. \& Nunn, B.L. Physiological responses of a Southern Ocean diatom to complex future ocean conditions. Nature Climate Change. 6, 207-213 (2016). doi: 10.1038/nclimate2811.

56. Deppeler, S.L. \& Davidson, A.T. Southern Ocean Phytoplankton in a Changing Climate. Frontiers in Marine Science. 4, 40 (2017). doi: 10.3389/fmars.2017.00040 


\section{Methods Only References}

57. Dickson, A.G., Sabine, C.L. \& Christian, J.R. Guide to best practices for ocean CO2 measurements, PICES Special Publication, North Pacific Marine Science Organization, Sidney, British Columbia, 2007.

58. Dickson, A.G. Standards for ocean measurements. Oceanography. 23, 34-47 (2010).

59. Shimizu, K., Del Amo, Y., Brzezinski, M.A., Stucky, G.D. \& Morse, D.E. A novel fluorescent silica tracer for biological silicification studies. Chemistry \& biology. 8, 1051-1060 (2001).

60. Leblanc, K. \& Hutchins, D.A. New applications of a biogenic silica deposition fluorophore in the study of oceanic diatoms. Limnology \& Oceanography: Methods. 3, 462-476 (2005).

61. McNair, H.M., Brzezinski, M.A. \& Krause, J.W. Quantifying diatom silicification with the fluorescent dye, PDMPO. Limnology \& Oceanography: Methods. 13, 587-599 (2015).

62. Baker, K.G., Robinson, C.M., Radford, D.T., McInnes, A.S., Evenhuis, C., Doblin, M.A. Thermal Performance Curves of Functional Traits Aid Understanding of Thermally Induced Changes in Diatom-Mediated Biogeochemical Fluxes. Frontiers in Marine Science. 3, 44 (2016).

63. Parambath, M., Hanley, Q.S., Martin-Martinez, F.J., Giesa, T., Buehler, M.J., Perry, C.C. The nature of the silicaphilic fluorescence of PDMPO. Physical Chemistry Chemical Physics. 18, 5938-48 (2016).

64. Strickland, J.D.H. \& Parsons, T.R. 1968. A practical handbook of seawater analysis, Ottawa, Canada, Fisheries Research Board of Canada.

65. Nelson, D.M., Smith Jr, W.O., Muench, R.D., Gordon, L.I., Sullivan, C.W. \& Husby, D.M. Particulate matter and nutrient distributions in the ice-edge zone of the Weddell Sea: Relationship to hydrography during late summer. Deep Sea Research Part A. Oceanographic Research Papers. 36, 191-209 (1989).

66. Schneider, C.A., Raspnad, W.S. \& Eliceiri, K.W. NIH image to imageJ: 25 years of image analysis. Nature methods. 9, 671-679 (2012).

67. Kreyling, J., Schweiger, A.H., Bahn, M., Ineson, P., Migliavacca, M., Morel-Journel, T., Christiansen, J.R., Schtickzelle, N. \& Larsen, K.S. To replicate, or not to replicate - that is the question: how to tackle nonlinear responses in ecological experiments. Ecology Letters. 21, 1629-38 (2018).

68. Cottingham, K.L., Lennon, J.T. \& Brown, B.L. Knowing when to draw the line: designing more informative ecological experiments. Frontiers in Ecology and the Environment. 3, 145-152 (2005).

69. Petrou, K. (2019) Antarctic diatom silicification diminishes under ocean acidification Australian Antarctic Data Centre - doi:10.26179/5c3e745a9b071. 


\section{Figure captions:}

A

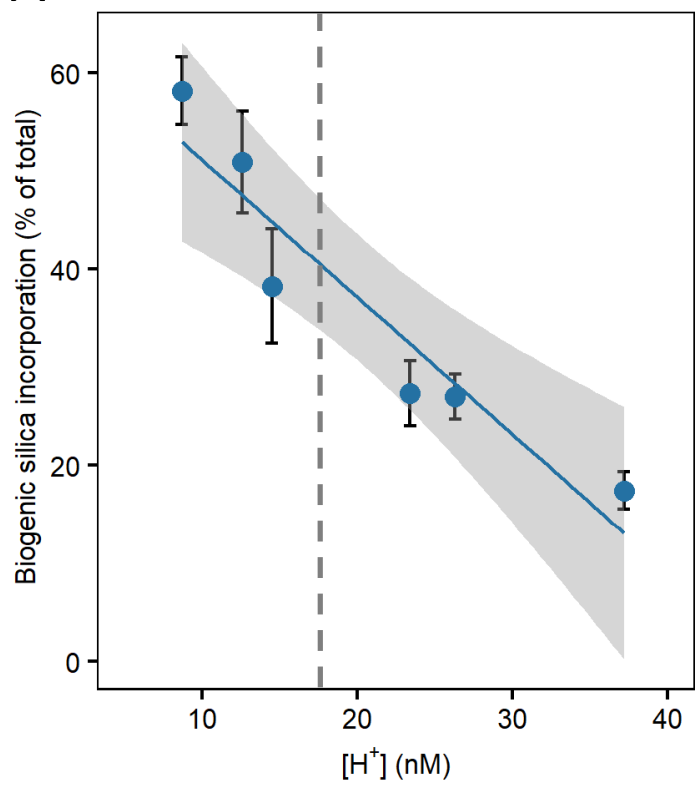

B

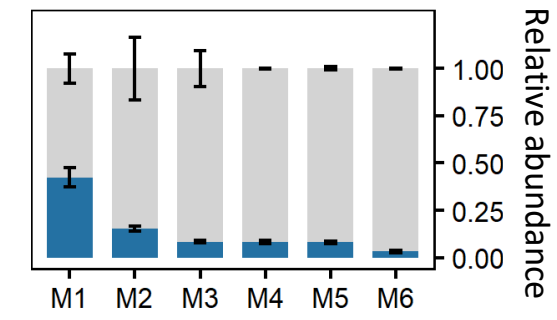

$<20 \mu \mathrm{m} \quad>20 \mu \mathrm{m}$

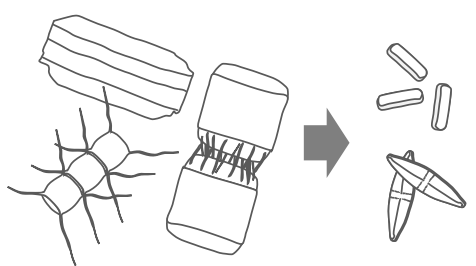

Figure 1| Silicification and diatom community composition on day 12. a, whole community biogenic

silica incorporation over $24 \mathrm{~h}$ as a function of $\left[\mathrm{H}^{+}\right]$, data represent the mean fluorescence from individual $24 \mathrm{~h}$ incubations $\pm \mathrm{SE}(n=3)$. Vertical dashed line denotes projected $\left[\mathrm{H}^{+}\right]$for the Southern Ocean by $2100{ }^{48}$. Blue line shows the linear regression with grey shaded $95 \%$ confidence intervals. b, proportion of small $(<20 \mu \mathrm{m})$ and large $(>20 \mu \mathrm{m})$ size fractions of diatoms on day 12 in each mesocosm. Proportional diatom abundance was calculated from mean cell counts, where error bars (SE) represent the pooled accuracy of counts from each mesocosm sample. Silicification data represent the mean fluorescence from individual $24 \mathrm{~h}$ incubations $\pm \operatorname{SE}(n=3)$, where three samples were taken from each mesocosm. 


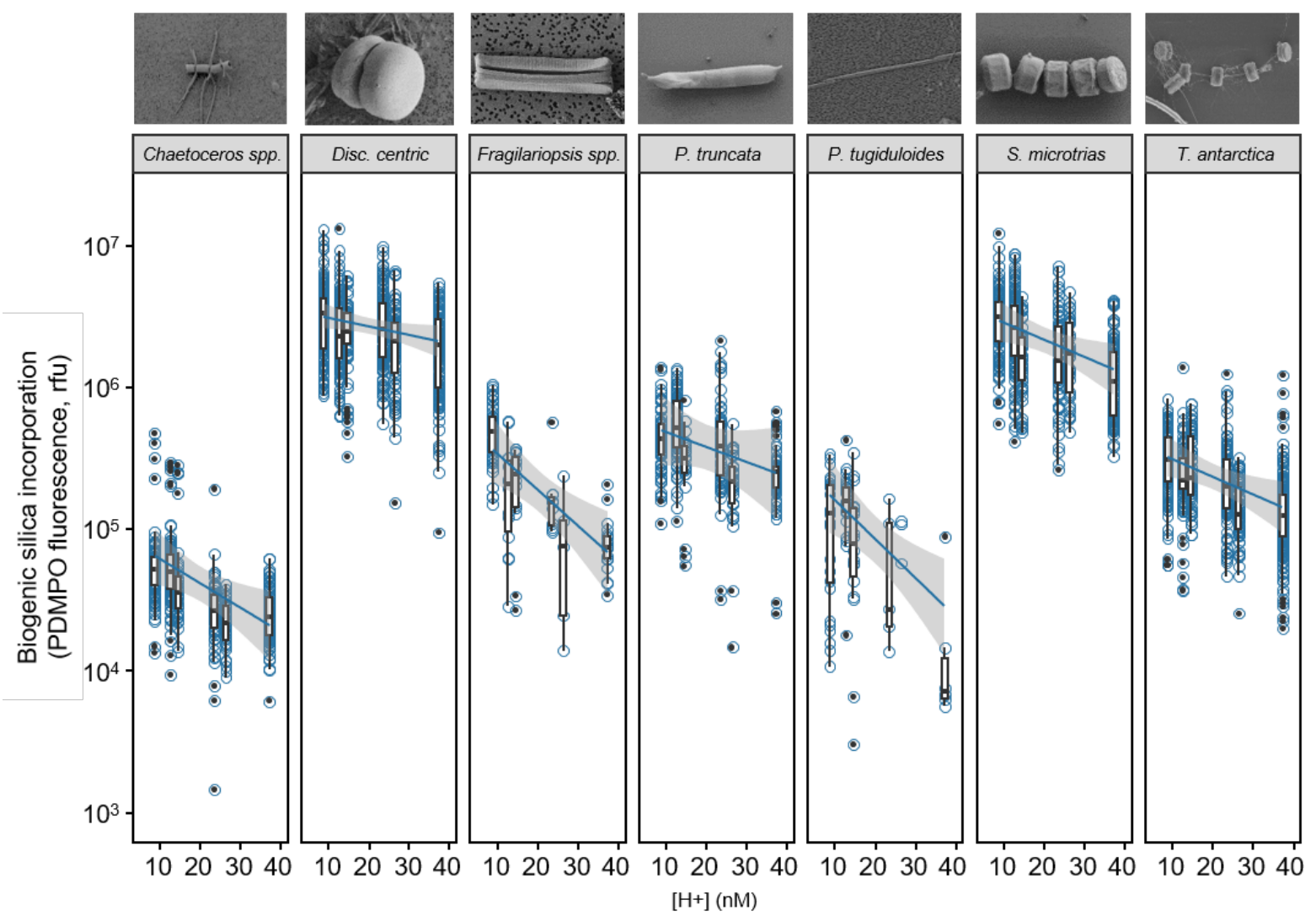

Figure 2| Single-celled silicification with $\left[\mathbf{H}^{+}\right]$. Biogenic silicate incorporation measured as total cell PDMPO fluorescence in Chaetoceros spp., Discoid centric, Fragilariopsis spp. (>20 $\mu$ m), Proboscia truncata, Pseudo-nitzschia turgiduloides, Stellarima microtrias and Thalassiosira antarctica. Data are visualised using box plots, with overlain blue rings showing the PDMPO fluorescence of individual cells from three individual 24 h PDMPO incubations. Data means (median $n=63$ ) are fitted with a model 1 linear regression (blue line; Supplementary Table 4) with 95\% confidence intervals (grey shading). A boxplot was not included for P. tugiduloides $\left[\mathrm{H}^{+}\right] 26.3$ because $\mathrm{n}=3$ (shown by blue rings). 
a
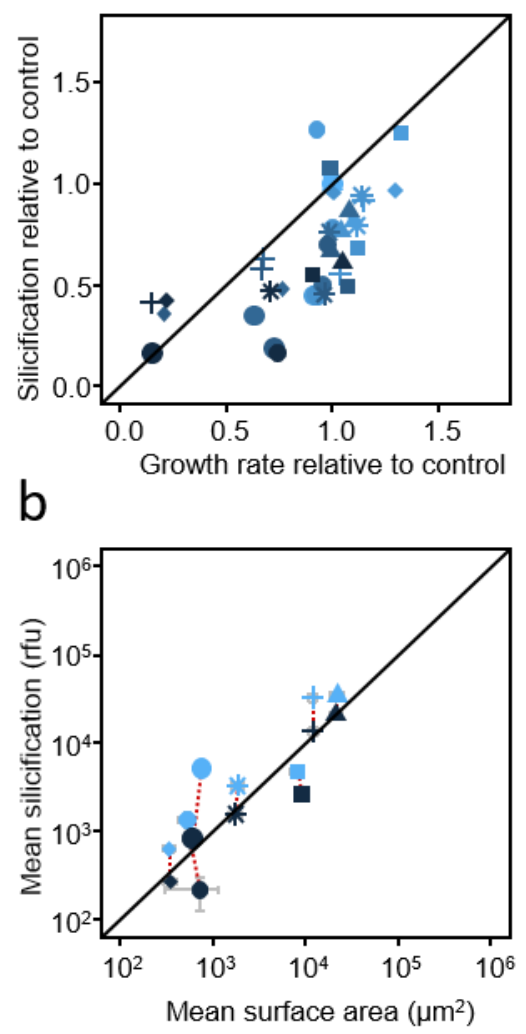

C

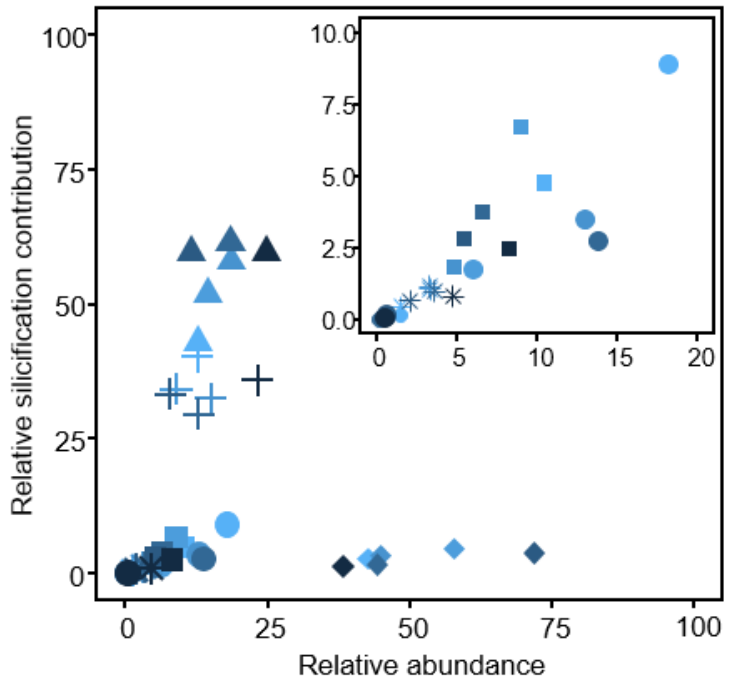

- Chaetoceros spp.

Discoid centric $>20 \mu \mathrm{m}$

Fragilariopsis spp. $>20 \mu \mathrm{m}$

P. truncata

- P. tugiduloides

+ S. microtrias

* T. antarctica

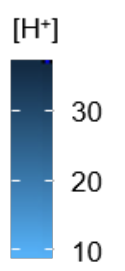

Figure 3| Silicification as a function of growth, cell surface area and abundance. a, relative specific growth rates do not explain changes in silicification of key taxa at each $\left[\mathrm{H}^{+}\right]$, black line shows the 1:1. b, taxon specific mean cell surface area $\left(\mu \mathrm{m}^{2}\right)$ is a good predictor of mean silicification $\left({ }_{A d j} R^{2}=0.763\right.$, $\left.\mathrm{F}_{1,5}=20.30 ; p=0.0064\right)$, and with the exception of Fragilariopsis spp. $<20 \mu \mathrm{m}$, this relationship doesn't change with increasing $\left[\mathrm{H}^{+}\right]$, red dashed lines link M1 with M6. ce, cell specific relative abundance and the proportional contribution of each taxon to community silicification with $\left[\mathrm{H}^{+}\right]$, detail of smaller and less abundant taxa can be seen in inset. For the relative abundance for Fragilariopsis spp. M4 modelled value was used. Colours represent $\mathrm{CO}_{2}$ levels, symbols indicate taxa. 


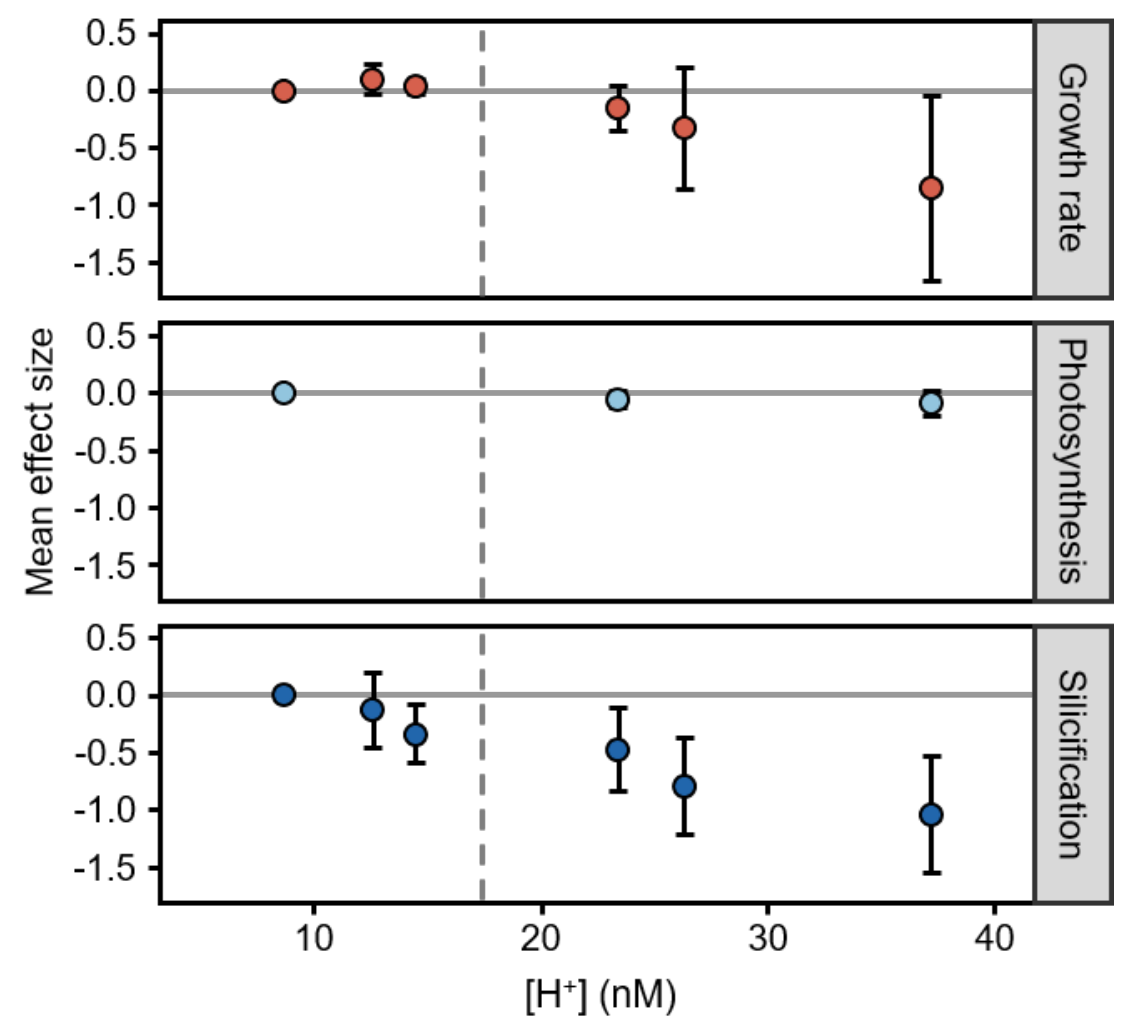

Figure 4| Diatom response to $\left[\mathbf{H}^{+}\right]$. Standardised empirical responses $( \pm 95 \%$ CIs $)$ of pooled data by major response variables, growth rate, photosynthesis and silicification. Responses are from growth rates (day 8-16) of selected diatom species $(n=8)$ from mesocosm incubations (Top), mean $\mathrm{F}_{\mathrm{v}} / \mathrm{F}_{\mathrm{M}}$ on day 12 of selected diatom taxa $(n=6)$ determined using single-cell microscopy PAM (Middle), and mean silicification of selected taxa $(n=7)$ after $24 \mathrm{~h}$ PDMPO incubation (Bottom). Data are presented as standardised mean effect size for levels of $\left[\mathrm{H}^{+}\right]$. The mean effect size is significant when the $95 \%$ confidence interval does not overlap zero. Vertical dashed line denotes projected $\left[\mathrm{H}^{+}\right]$for the Southern Ocean by $2100^{48}$. 